\title{
CEPU-1, a Novel Immunoglobulin Superfamily Molecule, Is Expressed by Developing Cerebellar Purkinje Cells
}

\author{
Frank Spaltmann and Thomas Brümmendorf \\ Max-Planck-Institut für Entwicklungsbiologie, D-72076 Tübingen, Germany
}

Proteins of the immunoglobulin superfamily (IgSF) are involved in a variety of specific cell-cell interactions in the developing nervous system. We used a systematic approach, based on the $\mathrm{PCR}$, to identify and characterize new members of this protein family in the developing chick nervous system. In this study, we report on CEPU-1, a new IgSF protein that is strongly expressed in developing Purkinje neurons in the cerebellum and is detectable on the dendrites, somata, and axons of these cells. The timing of CEPU-1 expression coincides with the growth of the dendritic tree-after the Purkinje cells have finished their migration from the ventricular zone. CEPU-1 is a $51 \mathrm{kDa}$ glycoprotein comprised of three lg-like domains of the $\mathrm{C} 2$ subcategory and is anchored to the plasma membrane via a post- translationally attached glycosyl-phosphatidylinositol moiety. The protein shows high sequence similarity to the neurotrimin glycoprotein ( $78 \%$ identity), to the opioid-binding cell adhesion molecule (or OBCAM; $68 \%$ identity), and to the limbic systemassociated membrane protein (or LAMP; $54 \%$ identity). Our results suggest that CEPU- 1 may serve as a cellular identification marker that is specific for developing Purkinje cells.

Key words: CEPU-1; cerebellum; Purkinje neurons; immunoglobulin superfamily; GPI membrane anchor; neurotrimin; opioid-binding cell adhesion molecule (OBCAM); limbic system-associated membrane protein (LAMP); cell surface markers; neural cell adhesion molecules; chick
Generation of specific connections of neurons during the embryonic development of the nervous system involves activityindependent mechanisms in early development, giving rise to coarse neural networks that are refined by activity-dependent mechanisms later in development (Goodman and Shatz, 1993; Gierer and Müller, 1995). In the context of activity-independent mechanisms of network formation, extending axons have to approach and identify their target regions. This phenomenon is based on the ability of the axonal growth cone to recognize diffusible factors (Tessier-Lavigne, 1994; Dodd and Schuchardt, 1995), extracellular matrix components (Reichardt and Tomaselli, 1991), and membrane-bound molecules in its environment (Hynes and Lander, 1992; Kapfhammer and Schwab, 1992; Sonderegger and Rathjen, 1992; Rutishauser, 1993). The latter may be subdivided into several classes, among them the integrins, the cadherins, and the molecules of the immunoglobulin superfamily (IgSF) (Wagner and Wyss, 1994).

In recent years, adhesion receptors of the IgSF, which are well established as mediators of specific cell-cell interactions in the immune system (Barclay et al., 1993; Clark and Ledbetter, 1994), have also been found to be involved in many histogenetic aspects of nervous system development (Rathjen, 1991; Sonderegger and Rathjen, 1992; Uyemura et al., 1994; Brümmendorf and Rathjen, 1995; Wong et al., 1995). For instance, IgSF molecules play a role in the migration of neuronal precursors, both on radial routes

\footnotetext{
Received Aug. 14, 1995; revised Nov. 29, 1995; accepted Dec. 6, 1995.

We thank A. Gierer and F. G. Rathjen for encouragement, stimulating discussions, and careful reading of this manuscript. We are grateful to C. Badger, S. Hagenmaier, A. Plagge, U. Treubert, E. Willbold, and J. P. Zanetta for helpful discussions and/or careful reading of this manuscript. We also thank S. Kurz and A. Schöffski for technical assistance, and C. Hug for secretarial help.

Correspondence should be addressed to Dr. Thomas Brümmendorf, Max-PlanckInstitut für Entwicklungsbiologie, Spemannstrasse 35/IV, D-72076 Tübingen, Germany.

Copyright (C) 1996 Society for Neuroscience $\quad 0270-6474 / 96 / 161770-10 \$ 05.00 / 0$
}

(Chuong, 1990; Barami et al., 1994) and on tangential routes (Ono et al., 1994; Schwanzel Fukuda et al., 1994). Glycoproteins of the IgSF are involved in the fasciculation of neurites (Brümmendorf and Rathjen, 1995; Pimenta et al., 1995; Stoeckli and Landmesser, 1995), in the guidance of axons (Tang et al., 1994; Stoeckli and Landmesser, 1995), and in contact-dependent induction of neurite outgrowth (Brümmendorf and Rathjen, 1995; DeBernardo and Chang, 1995; Nörenberg et al., 1995; Stoeckli and Landmesser, 1995; Zhukareva and Levitt, 1995). In contrast with these activating effects, IgSF molecules have also been found to mediate, under certain circumstances, contact-dependent inhibitory effects on axonal growth (Tiveron et al., 1992; McKerracher et al., 1994; Mukhopadhyay et al., 1994).

With respect to functional aspects of neural IgSF glycoproteins, ligands and receptors lave been identified and signal transduction mechanisms have been described. A neural IgSF molecule can interact in a homophilic manner or can be engaged in complex heterophilic interactions with multiple ligands that may be localized in the extracellular matrix or on cellular surfaces (Peles et al., 1995) (for review, see Brümmendorf and Rathjen, 1995). Furthermore, the recent analysis of signal transduction pathways triggered by neural IgSF adhesion receptors demonstrated that they do not function merely in adhesion, but also may act as signal transmitting receptors (for review, see Doherty and Walsh, 1994; Pierceall et al., 1994; Williams et al., 1994).

In the present study, we report on a novel glycosylphosphatidylinositol (GPI)-anchored member of the IgSF, which is strongly expressed by Purkinje cells, the principal neurons of the cerebellum (Eccles et al., 1967; Hawkes and Gravel, 1991; Jacobson, 1991; Sotelo and Wassef, 1991; Hatten and Heintz, 1995) and, therefore, is termed CEPU-1 in the following text. We characterize CEPU-1 by biochemical, structural, and histological criteria and discuss a putative role as a cellular address molecule (Sperry, 1963) specific for Purkinje cells. 
A

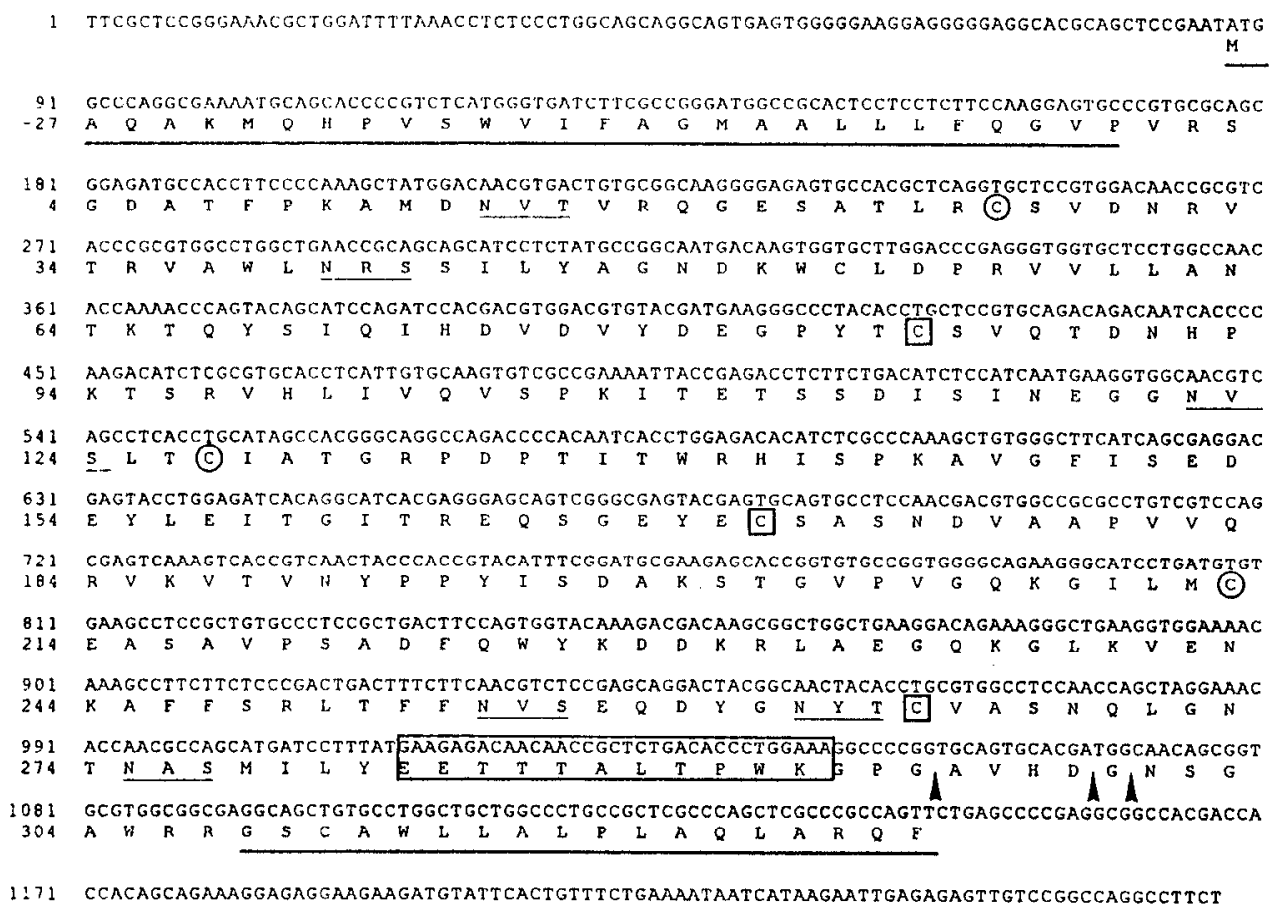

B

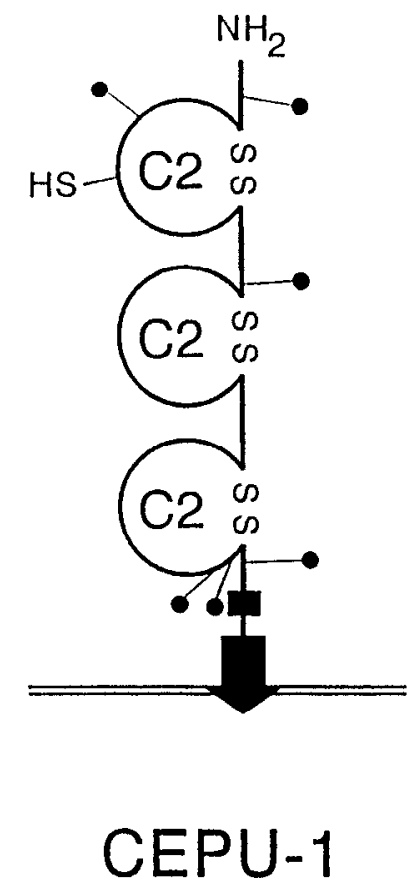

Figure 1. Structure of CEPU-1. A, Sequence of the cDNA and predicted primary structure of CEPU-1. Numbering of amino acids starts at the predicted $\mathrm{N}$-terminal Val of the mature polypeptide. The signal peptide cleavage site has been assigned by comparison with the LAMP sequence (Pimenta et al., 1995). The N-linked carbohydrate attachment sites are underlined, and the predicted signal peptide and C-terminal hydrophobic sequence are indicated by bold lines. $\mathrm{N}$ - and C-proximal Cys residues of each Ig-like domain are circled and boxed, respectively. Putative GPI-anchor attachment sites are indicated by arrowheads (Moran and Caras, 1991; Englund, 1993; Udenfriend and Kodukula, 1995). The alternatively spliced segment of 11 amino acids is indicated by a box. $B$, Domain model of CEPU-1. Ig-related domains are drawn as loops that are closed by disulphide bridges, the GPI-anchor is marked by an arrow, the unpaired Cys residue is marked $H S$, and the alternatively spliced segment as a filled box. Putative $\mathrm{N}$-linked glycosylation sites are shown as lines ending with dots.

\section{MATERIALS AND METHODS}

Amplification of $c D N A$ s encoding novel IgSF molecules by reverse transcriptase$P C R$. Polyadenylated mRNA from chicken embryonic day 11 (E11) to E13 tissue was isolated as described previously (Brümmendorf et al., 1989). Oligo(dT)-primed first-strand cDNA was synthesized using a reverse transcriptase (RT)-PCR kit (Stratagene, La Jolla, CA) under the conditions suggested by the supplier. To identify novel chick IgSF molecules via the PCR (Mullis and Faloona, 1987), we designed degenerated oligonucleotide primers. These primers were derived from the sequences RDAGVYEC (N-proximal) and GNYTCSAD (C-proximal), located around two C-proximal Cys residues of Ig-like domains of EMIP, a Drosophila melanogaster IgSF molecule (J. A. Knoblich and T. Brümmendorf, unpublished data). Closely related motifs can also be found in a series of other IgSF molecules, among them vascular cell adhesion molecule 1 (VCAM-1), neural cell adhesion molecule (NCAM), platelet/endothelial cell adhesion molecule 1 (PECAM-1), integrin-associated protein (IAP), fasciclin-2, sialoadhesin, F11, axonin-1, uncoordinated movement 5 (unc-5), or deleted in colorectal carcinoma (DCC) (Brümmendorf and Rathjen, 1995). The sequences of the $5^{\prime}$ primer and of the $3^{\prime}$ primer were $5^{\prime}$-GGACGCGTTA/ GA/CGIGAT/CGCIGGC/A/GGTT/C/A/GTAT/CGAA/GTG-3' and 5' - T T C G T A C G A/G T C T/A/C/G G C I G A A/G C A I G TA/GTAA/GTTG/T/CCC-3', respectively. PCR was performed with embryonic chick E11-E13 cDNA as a template using $50 \mathrm{U} / \mathrm{ml}$ Taq DNA polymerase (Pharmacia, Uppsala, Sweden) under the following conditions: $94^{\circ} \mathrm{C}$ for $1 \mathrm{~min}, 45^{\circ} \mathrm{C}$ for $3 \mathrm{~min}, 72^{\circ} \mathrm{C}$ for $1 \mathrm{~min}$ for $37 \mathrm{cycles}$, and then one final step with $72^{\circ} \mathrm{C}$ for $10 \mathrm{~min}$ in reaction buffer $\left(50 \mathrm{mM} \mathrm{KCl}, 1.5 \mathrm{mM} \mathrm{MgCl}_{2}, 10 \mathrm{mM}\right.$ Tris/Cl, $\mathrm{pH}$ 9). The reaction products were analyzed on a $2.5 \%$ Meta-Phor agarose gel (FMC Bioproducts, Rockland, ME).

Cloning of CEPU-1. DNA fragments generated by RT-PCR were purified using preparative gel electrophoresis (NA agarose, Pharmacia) and Qiaex reagents (Qiagen, Hilden, Germany) and were blunt-endsubcloned into the plasmid pBluescript (Stratagene). Full-length clones were obtained by screening a $\lambda \mathrm{gt} 11$ chicken brain E16 cDNA library (Brümmendorf et al., 1989) using a digoxigenin-labeled CEPU-1 probe generated from the cloned DNA fragment. Preparation of this probe, hybridization, washing, and staining conditions were the same as described below for the genomic Southern analysis.

Nucleotide sequences were determined by the dideoxy chaintermination method (Sanger et al., 1977) using the automated laser fluorescent (ALF) DNA sequencer and DNA sequencing kits recommended by the supplier (Pharmacia).

Genomic Southern blot analysis. Chicken liver genomic DNA $(18 \mu \mathrm{g})$ was digested by restriction endonucleases Bam HI and EcoRI (Boehringer Mannheim, Mannheim, Germany), electrophoresed on a $0.5 \%$ agarosegel, and blotted onto a positively charged nylon membrane (Boehringer). A 327 bp digoxigenin-labeled CEPU-1 probc, corresponding to nuclcotides 655-982 of the CEPU-1 sequence (Fig. $1 \mathrm{~A}$ ), was prepared via PCR (Lanzillo, 1991), and the PCR-product was purified by agarose gel electrophoresis. After overnight incubation at $68^{\circ} \mathrm{C}$ with the digoxigeninlabeled CEPU- 1 probe in hybridization buffer $[5 \times \mathrm{SSC}, 0.1 \%$ laurylsarcosine, $0.02 \%$ SDS, and $1 \%$ blocking reagent (Boehringer)], the nylon membrane was washed twice for 5 min with $2 \times$ SSC/0.1\% SDS at room temperature and twice for $15 \mathrm{~min}$ with $0.2 \times \mathrm{SSC} / 0.1 \% \mathrm{SDS}$ at $68^{\circ} \mathrm{C}$. The membrane was developed using alkaline phosphatase-coupled antidigoxigenin antibodies for detection (Boehringer) and 5-bromo-4-chloro3-indolyl phosphate/nitro blue tetrazolium as substrate (Mierendorf et al., 1987).

Expression of CEPU-1 in bacteria and generation of antibodies in rabbits. The part of CEPU-1 lacking the N- and C-terminal stretches was amplified by PCR using primers with BamHI sites at their 5' ends. The fragment was subcloned into the expression vector pQE12 (Qiagen), which provides a $\mathrm{His}_{6}$ tag $\mathrm{C}$-terminal in-frame to the CEPU-1 sequence. Sequence analysis of the construct revealed a single nucleotide exchange, presumably caused by the PCR process, which altered Asn in position 14 
of the CEPU-1 protein to Asp. The Escherichia coli strain M15 (Qiagen) was transformed with the construct, and the bacteria were grown to an $\mathrm{OD}_{600}$ of $0.7-1.0$ in TB medium. Protein expression was induced with 0.2 mM isopropyl $\beta$-D-thiogalactopyranoside (Promega, Madison, USA), and the bacteria were cultivated for 5 additional hours. The bacteria were lysed in $6 \mathrm{M}$ guanidinium hydrochloride $/ 0.1 \mathrm{M} \mathrm{NaH}_{2} \mathrm{PO}_{4} / 0.01 \mathrm{M}$ Tris, $\mathrm{pH}$ 8.0 , and CEPU-1-His 6 protein was purified by $\mathrm{Ni}^{2+}$-chelate affinity chromatography (Hochuli et al., 1988). Column washing and elution were performed as suggested by the manufacturer (Qiagen). The His-tagged CEPU-1 protein was purified further by preparative SDS-PAGE, followed by electroelution using the biotrap-device (Schleicher \& Schuell, Dassel, Germany). Rabbits were immunized with a suspension of $100-500$ $\mu \mathrm{g}$ of CEPU-1 protein in complete Freund's adjuvant (Gibco, Grand Island, NY) and were boosted several times with the same amount of protein in incomplete Freund's adjuvant. Antisera were preabsorbed with chicken liver acetone powder (Sigma, St. Louis, MO) and were affinitypurified on a CEPU-1 Sepharose column produced by coupling CEPU-1 protein to cyanbromide-activated Sepharose (Pharmacia).

Analysis of membrane anchorage and transfection of COS cells. Preparation of embryonic chick brain plasma membranes (Rathjen et al., 1987) and release of GPI-linked proteins by phosphatidylinositol-specific phospholipase C (PI-PLC) (Wolff et al., 1989) were performed essentially as outlined previously. In the present study, membranes were suspended in $20 \mathrm{~mm}$ Tris- $\mathrm{Cl}, \mathrm{pH} 7.4$, with $10 \mu \mathrm{M}$ leupeptin, $10 \mu \mathrm{M}$ pepstatin, and 40 $\mathrm{U} / \mathrm{ml}$ aprotinin. Membranes were incubated for $1.5 \mathrm{hr}$ at $37^{\circ} \mathrm{C}$ using 2 $\mathrm{U} / \mathrm{ml}$ recombinant PI-PLC from Bacillus thuringiensis (Oxford GlycoSystems, Abingdon, UK). SDS-PAGE and immunoblots were done essentially as described in Rathjen et al. (1991).

For COS cell transfection, the full-length coding sequence of CEPU-1 was subcloned into the eukaryotic expression vector pSG5 (Stratagene). Transfection and immunofluorescence analysis of COS cells were performed essentially as described previously (Brümmendorf et al., 1993). COS cells were grown in DMEM/2\% fetal calf serum (FCS) instead of $\mathrm{DMEM} / 10 \%$ FCS as we have done previously.

Immunohistochemistry. Chicken eggs were incubated at $37.3-37.8^{\circ} \mathrm{C}$ with relative humidity of $52-57 \%$. Dissected parts of chicken brains were fixed overnight in PBS/4\% formaldehyde and incubated overnight in Tris-buffered saline (TBS) $/ 25 \%$ sucrose. The tissue was sectioned using a cryostat microtome (Frigocut, Reichert-Jung, Nußloch, Germany) after embedding in tissue tek (Miles, Elkhardt, IN). Twenty-micrometer-thick slices were collected on gelatin-pretreated glass microscope slides and stored at $-20^{\circ} \mathrm{C}$. Sections were blocked for $30 \mathrm{~min}$ with $\mathrm{TBS} / 2 \%$ bovine serum albumin $/ 0.05 \%$ Tween $20 / 0.1 \% \mathrm{NaN}_{3}$, and incubated for $2 \mathrm{hr}$ using affinity-purified anti CEPU-1 antibody $(10 \mu \mathrm{g} / \mathrm{ml})$ in combination with the DNA-staining reagent bisbenzimide (H33258, Boehringer). After washing three times with blocking buffer, the slices were incubated for 2 hr with goat anti-rabbit antibodies conjugated with the fluorochrome Cy3 (Dianova, Hamburg, Germany). After washing, the slices were mounted using Kaiser's glycerine gelatin (Merck, Darmstadt, Germany).

\section{RESULTS}

\section{Cloning of CEPU-1 via PCR}

In an attempt to extend our present knowledge on IgSF molecules and their roles in nervous system histogenesis, we are interested in the identification and characterization of new members of this family. A characteristic feature of IgSF molecules is the Ig-like domain, a structure comprised of $\sim 75-100$ amino acids arranged in two opposing $\beta$ sheets and, in most cases, an intradomain disulphide bridge. Ig-like domains show a bimodal distribution of the extent of their evolutionary sequence conservation (Williams and Barclay, 1988; Brümmendorf and Rathjen, 1993). This conservation is based on characteristic sequence elements that can be found in the vicinity of the $\mathrm{N}$-proximal Cys residue and, more clearly, the $\mathrm{C}$-proximal Cys residue. To identify novel nervous system molecules of the IgSF, we therefore developed PCRprimers that represent amino acid sequences around the C-proximal Cys residue of an Ig-like domain of EMIP, an IgSF protein of Drosophila melanogaster (J. A. Knoblich and T. Brümmendorf, unpublished data). PCR experiments, using singlestranded cDNA reverse-transcribed from E11-E13 chicken brain

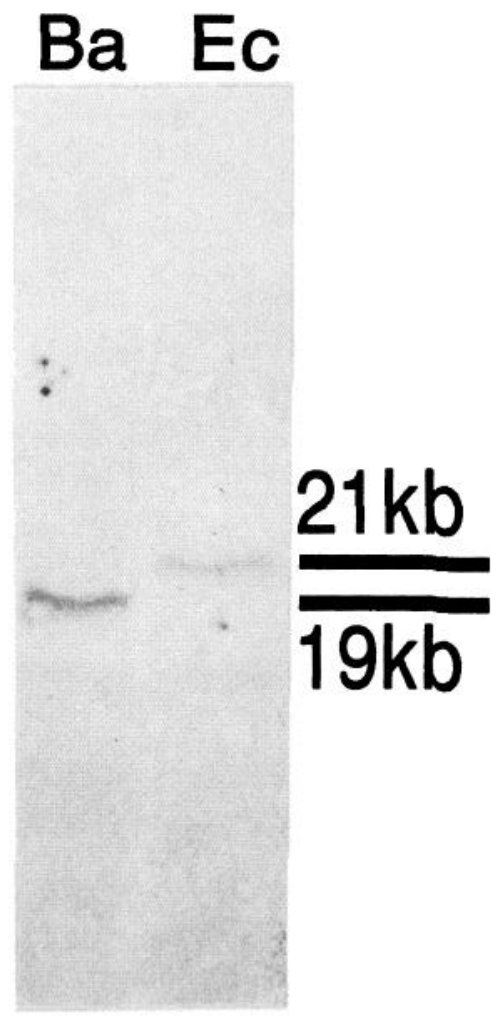

Figure 2. CEPU-1 is a single-copy gene. Genomic chicken DNA was digested with restriction endonucleases Bam HI $(B a)$ and $E c o$ RI $(E c)$, transferred to a nylon membrane, and probed by hybridization using a fragment of the CEPU-1 cDNA under conditions revealing perfect matches.

mRNA as a template, yielded a prominent broad band of $330 \mathrm{bp}$, presumably representing a population of fragments (data not shown). The length of these DNA fragments is sufficient to encode 110 amino acids and, therefore, is in agreement with the expected distance between two C-proximal Cys residues of two adjacent Ig-like domains. The population of fragments was subcloned into a plasmid vector, and 14 clones were sequenced. One clone was found to represent NCAM, one sequence could not be categorized, and 12 sequences were found to belong to three until now unknown IgSF molecules. One of the new partial clones was used to screen an embryonic chick $\lambda$ gt11 cDNA library (Brümmendorf et al., 1989) by DNA hybridization techniques. Screening $\sim 1 \times 10^{6}$ phage plaques yielded two identical full-length phage clones. Their inserts were subcloned into a plasmid vector and sequenced. Assembly of both sequences revealed that both phage clones represent the same mRNA containing one open reading frame of 342 amino acids (Fig. 1A). Because the protein encoded by this mRNA is predominantly expressed by cerebellar Purkinje cells (see below), we will refer to it as CEPU-1 in the following text.

CEPU-1 has an N-terminal and a C-terminal stretch of hydrophobic amino acids, representing a putative leader sequence and a putative signal for post-translational attachment of a GPI membrane anchor, respectively (Englund, 1993; Udenfriend and Kodukula, 1995). It comprises three Ig-like domains of the C2 subcategory and six potential Asn-linked glycosylation sites (Fig. $1 B)$, and is encoded by a single-copy gene as demonstrated by Southern blot analysis (Fig. 2). CEPU-1 is highly similar to neurotrimin, opioid-binding cell adhesion molecule (OBCAM), and 
limbic system-associated membrane protein (LAMP) and is more distantly related to NCAM, F11, and other nervous system IgSF molecules. It shows $78 \%$ amino acid sequence identity with neurotrimin, $68 \%$ with OBCAM, and $54 \%$ with LAMP from the rat (Lippman et al., 1992; Pimenta et al., 1995; Struyk et al., 1995), but $<25 \%$ with rat NCAM, TAG-1/axonin-1, and F3/F11 (Small et al., 1987; Furley et al., 1990; Hosoya et al., 1995).

The mature CEPU-1 polypeptide has an uneven number of Cys residues, suggesting that, based on sequence alignments, Cys-53 is unpaired and not involved in an intradomain disulphide bridge. Although Cys-53 is likely to be exposed, we could not obtain evidence for CEPU-1 dimerization via disulphide bridges or evidence for the existence of disulphide-linked heterodimers containing CEPU-1 (data not shown).

To obtain first indications on the tissue distribution of CEPU-1, RT-PCR experiments using PCR primers that flank the coding region of the mature protein on the CEPU-1 cDNA were performed on mRNA samples isolated from different tissues. CEPU-1 mRNA was detectable in E15 telencephalon, tectum, and cerebellum as well as in total brain mRNA of E8-E16, but it was undetectable in E14 liver, heart, and lung (data not shown). Interestingly, the RT-PCR experiments revealed the presence of two amplification products differing in yield and size (data not shown). Cloning and sequencing of both amplified DNA fragments showed that CEPU-1 exists in a major and a minor isoform. Both forms differ by a segment of 11 amino acids that is only present in the minor form and that is localized at the C-terminal end of the third Ig-like domain, close to the putative GPI-anchor attachment site (Fig. 1A).

\section{CEPU-1 is a $\mathbf{5 1} \mathrm{kDa}$ neural cell surface glycoprotein}

To characterize CEPU-1 further with respect to biochemical, histological, and functional aspects, polyclonal antibodies were raised in rabbits. The CEPU- 1 cDNA lacking the signal peptide and the $\mathrm{C}$-terminal hydrophobic stretch was subcloned in the bacterial expression vector $\mathrm{pQE12}$, in-frame with a C-terminal tag of six His residues (Hochuli et al., 1988). The stretch of His residues allows the purification of this protein, which is referred to as CEPU-1-His ${ }_{6}$ in the following text, from bacterial lysates by $\mathrm{Ni}^{2+}$ chelate affinity chromatography.

CEPU-1-His ${ }_{6}$ was expressed in bacteria and was subsequently purified from bacterial lysates using $\mathrm{Ni}^{2+}$ chelate affinity chromatography followed by preparative SDS-PAGE. Two rabbits were immunized with CEPU-1-His ${ }_{6}$, and their antisera were affinitypurified using CEPU-1-His ${ }_{6}$ immobilized on a Sepharose column. Affinity-purified antisera from both rabbits behaved indistinguishably and revealed a broad band of $51 \mathrm{kDa}$ in solubilized samples of E18 cerebellum (Fig. 3A, lane 5), telencephalon, and tectum (data not shown). As a consistency control, COS cells were transfected with CEPU-1 cDNA that had been cloned in the eukaryotic expression vector pSG5. Lysates of CEPU-1-transfected and -untransfected COS cells were subjected to immunoblot analysis using the polyclonal antibody directed to bacterially expressed CEPU-1-His ${ }_{6}$. CEPU-1 expressed by COS cells was found to have the same $M_{\mathrm{r}}$ as CEPU-1 in samples of solubilized embryonic cerebellum, and this band can be considered specific because no signal was detectable in lysates of untransfected COS cells (Fig. $3 A$, lanes 1 and 2). Whereas the $M_{\mathrm{r}}$ of CEPU-1, as calculated from the predicted amino acid sequence, amounts to $37 \mathrm{kDa}$, its $M_{\mathrm{r}}$ in SDS-PAGE is $51 \mathrm{kDa}$. The discrepancy is unlikely to be attributable to abnormal electrophoretic mobility of the protein back-

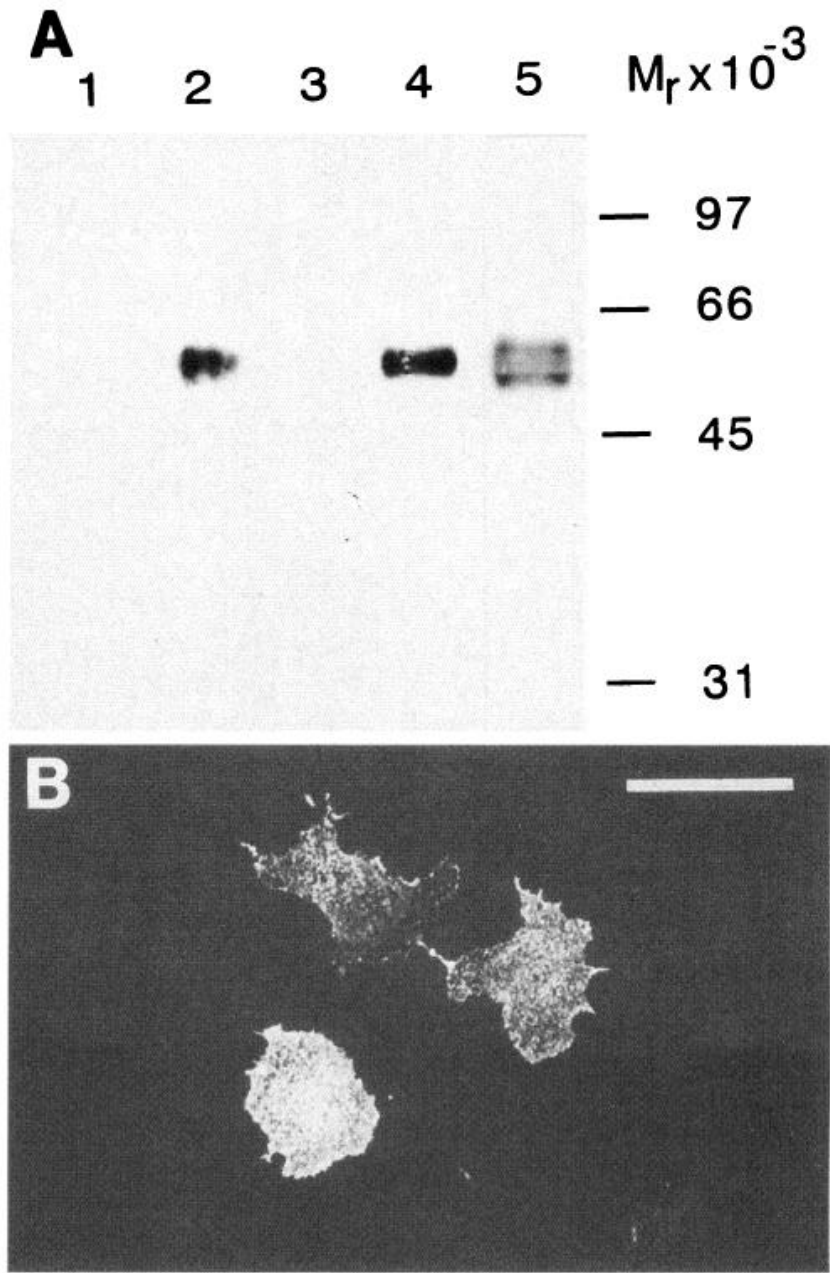

Figure 3. Biochemical analysis and COS cell transfection. $A$, SDS-PAGE and immunoblot analysis using CEPU-1-specific antibody. Lane 1, Untransfected COS cells solubilized in sample buffer. Lane 2, CEPU-1transfected COS cells. Both COS cell samples represent $0.5 \mathrm{~cm}^{2}$ of confluent cells. Lane 3, Supernatant of E16 chick brain membranes incubated with PI-PLC that was inactivated by $\mathrm{Zn}^{2+}$. Lane 4 , Supernatant of E16 brain membranes incubated with PI-PLC. Lane 5, E18 chick cerebellum solubilized in SDS-PAGE sample buffer (the lane represents $10 \mu \mathrm{l}$ of a $10 \%$ tissue homogenate). $B$, CEPU-1 expressed on the surface of transfected COS cells. COS cells were transfected with CEPU-1 cDNA that was cloned in the eukaryotic expression vector pSG5. Confluent cells were subjected to immunofluorescence analysis using CEPU-1-specific antibodies and Cy3-conjugated secondary antibodies. Scale bar, $100 \mu \mathrm{m}$.

bone, but is most likely the result of glycosylation, suggesting that $28 \%$ of the molecular mass is attributable to carbohydrates.

\section{CEPU-1 is a GPI-linked cell surface protein}

The CEPU-1 sequence has a C-terminal stretch of 18 predominantly hydrophobic amino acids (Fig. 1A). This is a characteristic feature of proteins linked to the plasma membrane by covalent post-translational attachment of a GPI moiety (Englund, 1993; Udenfriend and Kodukula, 1995). The presence of a C-terminal hydrophobic stretch within a protein sequence represents no formal proof of GPI-anchorage; rather, it can only be taken as evidence for this mode of membrane attachment. Therefore, we examined experimentally whether CEPU-1 can be cleaved from the cell membrane by PI-PLC, an enzyme known to release GPI-linked proteins. Embryonic chick brain plasma membranes were incubated with PI-PLC; the supernatant was separated from 

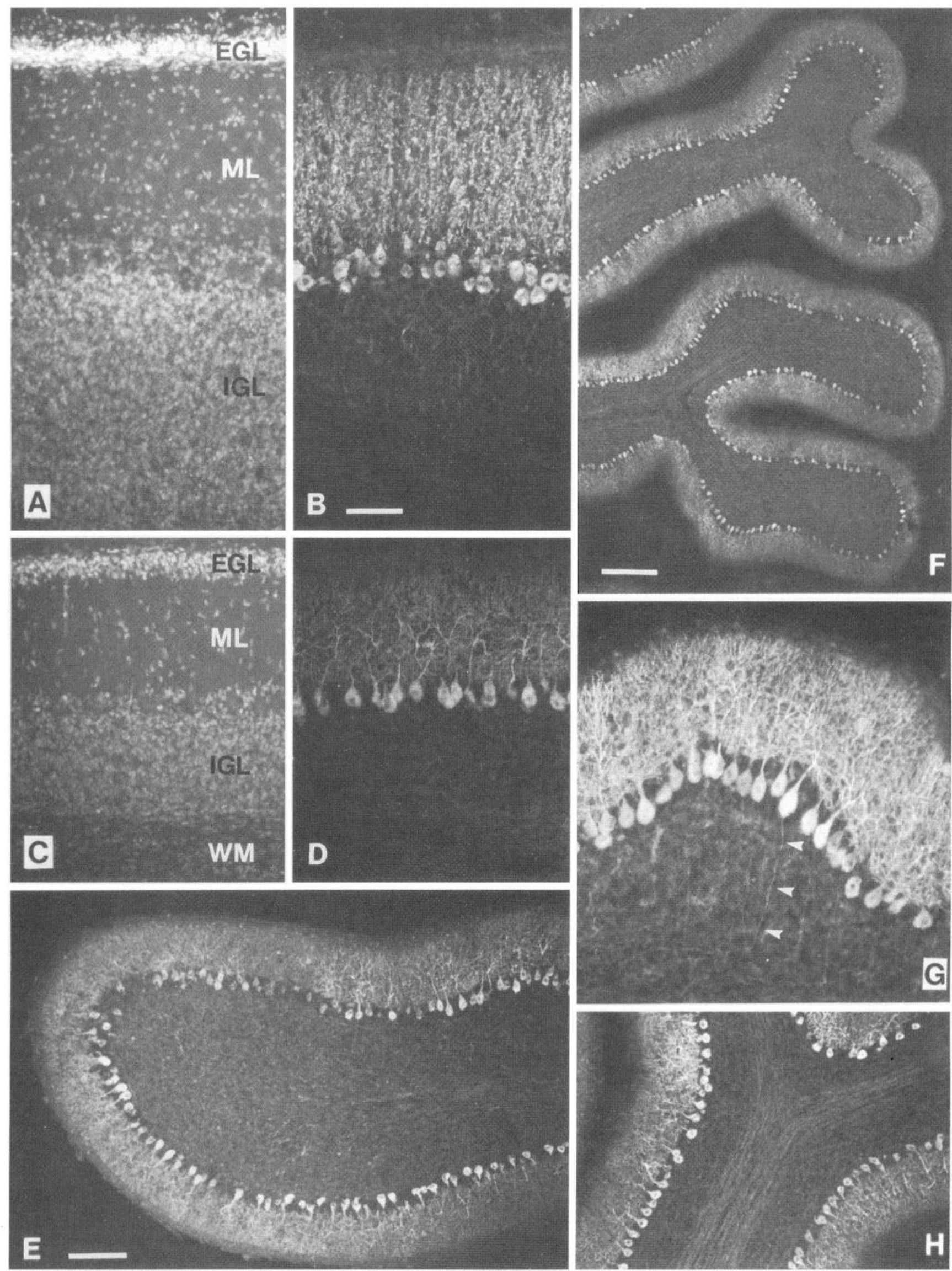
cell membranes, and both were subjected to immunoblot analysis using CEPU-1-specific antibodies. In line with the presence of its putative GPI-anchor attachment signal, CEPU-1 was found to be released from cell membranes by PI-PLC (Fig. $3 A$, lane 4). No release was observed in the presence of $\mathrm{Zn}^{2+}$, a cation known to inhibit PI-PLC activity, or in the absence of PI-PLC (Fig. $3 A$, lane 3) (data not shown). Therefore, release of CEPU-1 was mediated by PI-PLC and not by any contaminating protease. CEPU-1 was undetectable in cell membrane pellets after PI-PLC treatment (data not shown), suggesting that the cleavage was quantitative. To demonstrate further that CEPU-1 is a cell surface molecule, COS cells were transfected with CEPU- 1 cDNA and analyzed by immunofluorescence analysis using CEPU-1-specific antibodies. Staining of CEPU-1-transfected COS cells (Fig. $3 B$ ) and lack of staining of untransfected COS cells (data not shown) confirms that CEPU-1 is a cell surface protein and that the antibodies recognize the native, glycosylated form of the molecule. Taken together, these results strongly suggest that CEPU- 1 is anchored to the cell membrane by post-translational attachment of a GPI anchor.

\section{CEPU-1 is expressed by cerebellar Purkinje cells}

As a first step in analyzing the biological function of the molecule, CEPU-1-specific antibodies were used for immunohistochemical analyses. Examination of sections of E14-E20 chick cerebellum, E8-E20 telencephalon, and E10-E20 tectum revealed two different aspects of the histological distribution of CEPU-1. First, CEPU-1 is strongly expressed in Purkinje cells of the cerebellum and, second, CEPU-1 is expressed as a diffuse staining at E20 in the other brain regions examined (data not shown).

A horizontal section through the top of an E19 cerebellar folium shows the external granular layer (EGL), the molecular layer (ML) and the internal granular layer (IGL) as revealed by the high and low densities of cellular nuclei in the granular layers and the molecular layer, respectively (Fig. 4A). Immunohistochemical analysis of the same section using CEPU-1-specific antibodies reveals Purkinje cells with their cell bodies between the ML and the IGL and with their dendritic arborizations localized in the ML (Fig. 4B). No staining could be observed if the antibody dilution buffer was applied without primary antibody (not shown). To support this interpretation that CEPU-1 is expressed on Purkinje cells, sagittal sections of cerebellar folia were analyzed by staining cellular nuclei and by CEPU-1 immunohistochemistry. Sagittal sections through E19 cerebellar cortex demonstrate CEPU-1 expression on the pear-shaped cell bodies of the Purkinje cells, and their elaborate dendrites flattened in the sagittal plane (Fig. $4 C, D$ ). The somata of the Purkinje cells are found to be arranged in a single row with no significant difference in the density of cells between the top and the bottom of E19 cerebellar folia (Fig. $4 E, F$ ).

At this stage of development, when the Purkinje cell dendrites have almost reached their final size, CEPU-1 expression is first discernible in other regions of the cerebellum, namely in the IGL and in the prospective white matter (WM). It is evenly distributed in a slightly scattered manner, becoming more prominent at later developmental stages (Fig. $4 G, H$ ). A weak staining of subsets of cells in the deep cerebellar nuclei is also discernible at later embryonic stages (data not shown). However, the evenly distributed, scattered signal of CEPU-1 expression in the IGL is overlaid by a clear staining of thin fibers emanating from the bottom of the Purkinje cell bodies, most likely representing Purkinje cell axons (Figs. 4G, arrowheads). Consistently, CEPU-1 immunoreactivity is also found on broad bundles of fibers in the prospective WM of E19 cerebellar folia (Fig. $4 H$ ). It can be assumed that these bundles represent Purkinje cell axons projecting to the deep cerebellar nuclei.

\section{CEPU-1 expression on Purkinje cells coincides with the growth of the dendritic tree}

In chicken, Purkinje cells have completed their migration from the ventricular zone to their final position between the ML and the IGL by $\mathrm{E} 9$ and are aligned in a single layer of cells by E15 (Obata and Fujita, 1984; Bertossi et al., 1986; Sheppard et al., 1988; Hallonet et al., 1990). CEPLI-1 immunoreactivity, however, is not detectable on Purkinje cells between E9 and E14. It is first discernible at E15 within the prospective Purkinje cell layer as a weak signal in scattered spots that are smaller than the Purkinje cell bodies (Fig. 5, E15). Therefore, Purkinje cells are lacking CEPU-1 expression during their migration from the ventricular zone and begin to express the protein at E15, coinciding with the growth of their dendritic tree. At E16, CEPU-1 staining on the characteristic pear-shaped bodies of the Purkinje cells has reached its final intensity, and a dendrite with the length of the cell bodies is clearly visible (Fig. 5, E16). Between E16 and E19, the number of branch points and the average branch length of the dendrites increase (Fig. 5, E18). Simultaneously, the thickness of the dendrites seems to decrease slightly during this period. It can be estimated that the leading edge of the dendritic trees extends with $\sim 50 \mu \mathrm{m} / \mathrm{d}$, and it reaches its final position between E19 and F.20. Putative Purkinje cell axons, which are occasionally visible early in development (Fig. 5, E16, arrowhead), are frequently found to be CEPU-1-positive at later stages when the dendrite has reached its final size (Fig. $4 G$ ).

\section{DISCUSSION}

The present study is part of a systematic search for novel IgSF molecules in the developing chick nervous system. In this report, we characterize CEPU-1, a GPI-anchored glycoprotein comprised of three C2-type Ig-like domains that is strongly expressed by developing Purkinje cells and, at lower levels, in other regions of the CNS.

\section{Potential roles of CEPU-1 in cerebellar histogenesis}

Hypotheses concerning the function of CEPU-1 on developing Purkinje cells have to take into account that CEPU-1 is not

$\leftarrow$

Figure 4. CEPU-1 expression in cerebellar Purkinje cells. $A$, Horizontal section through the top of an E19 chick cerebellar folium. Bisbenzimide staining of cellular nuclei indicates the nuclei-poor $M L$ between the thin $E G L$ and the broad $I G L$. B, Same field as in $A$. Immunothuorescence analysis using CEPU-1-specific antibodies shows cell bodies of Purkinje cells and Purkinje cell dendrites that are cut perpendicular to the dendritic sheet. $C$, Sagittal section through E19 cerebellar cortex. The granular layers, the $M L$, and the prospective white matter $(W M)$ are revealed by bisbenzimide staining of cellular nuclei. $D$, Same field as in $C$. Immunofluorescence analysis using CEPU-1-specific antibodies reveals Purkinje cells with their dendritic arborizations, which are flattened in the sagittal plane. $E, F$, CEPU-1 distribution in sagittal sections of E19 cerebellar folia. $G$, CEPU-1 localization on Purkinje cell dendrites and axons (arrowheads) in a sagittal section of F20 cerebellar cortex. $H$, CF.PIJ-1 expression in the prospective WM of E19 cerebellum. A sagittal section of the branching region of two subfolia is shown. Scale bars: $A-D, G$ (shown in $B$ ), $100 \mu \mathrm{m} ; E, H$ (shown in $E$ ), $200 \mu \mathrm{m}$; $F, 400 \mu \mathrm{m}$. 

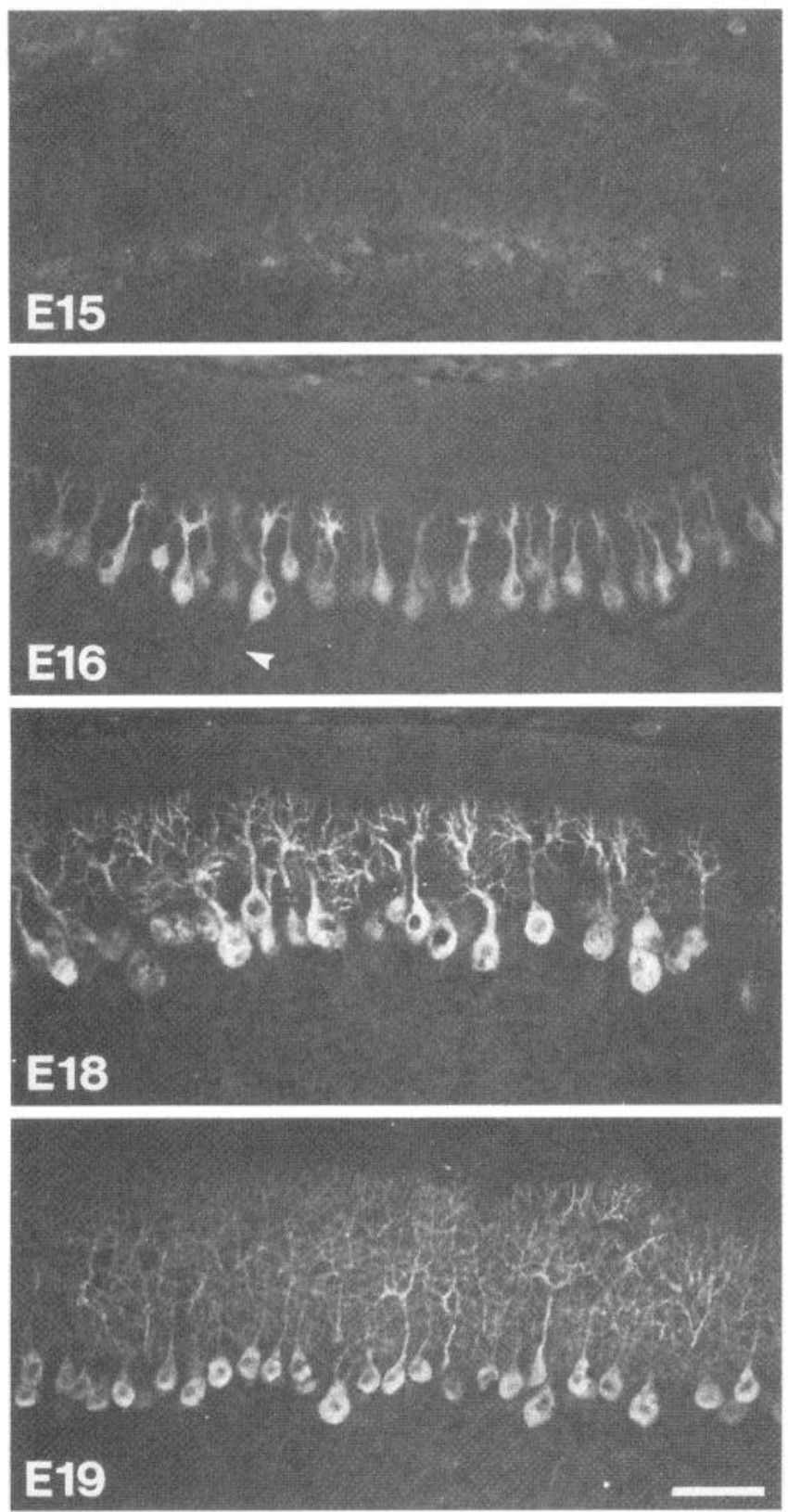

Figure 5. Development of Purkinje cell dendritic arborizations. Immunofluorescence analysis of sagittal sections through chick cerebellar cortex of E15-E19 using CEPU-1-specific antibodies. Because cerebellar folia do not develop isochronically (Altman and Bayer, 1985; Feirabend, 1990; Goodlett et al., 1990), fields that are typical for each embryonic stage have been chosen. CEPU-1 is first discernible at E15 as weakly stained spots that are localized within the prospective Purkinje cell layer. At E16 the protein is clearly recognizable on the somata and dendrites of the Purkinje cells. The number of branch points of the dendrites and the average branch length increases between E16 and E19, and axons are rarely discernible during these stages (arrowhead). Stage E17 has been omitted, because it is similar to E18. Scale bar, $100 \mu \mathrm{m}$.

present on migrating Purkinje cells but is expressed only after they have reached their final position coinciding with the outgrowth of the dendritic tree (Fig. 6). In chicken, Purkinje cells have completed their migration to the zone beneath the EGL by E9 (Hallonet et al., 1990; Pourquie et al., 1992). At E15, the Purkinje cells are aligned in a single layer of cells with a sprouting apical dendrite (Foelix and Oppenheim, 1974; Palacios-Prü et al., 1981;

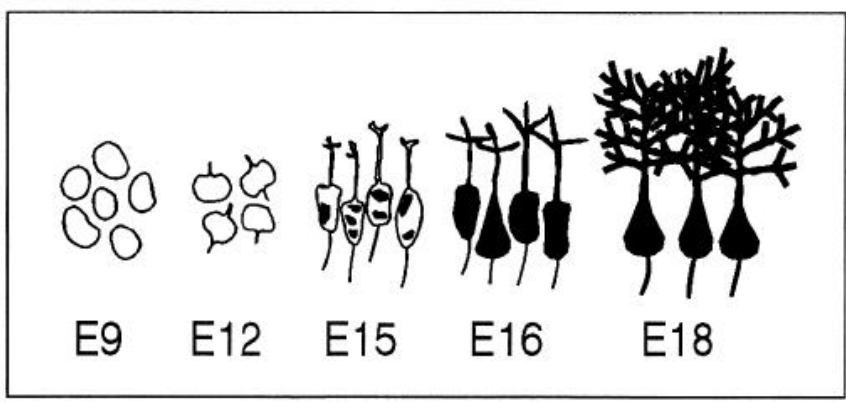

Figure 6. Purkinje cell alignment and polarization. Schematic representation of Purkinje cell development in chicken cerebellum between $E 9$ and E18 (sagittal plane) based on the present report and on studies that describe Purkinje cell differentiation in the chick (Foelix and Oppenheim, 1974; Bertossi et al., 1986; Sheppard et al., 1988). Expression of CEPU-1 is depicted in black.

Obata and Fujita, 1984; Bertossi et al., 1986; Sheppard et al., 1988).

CEPU-1 is first discernible at E15 in the Purkinje cell layer and is strongly expressed on Purkinje cell dendrites, somata, and axons at E16. The protein continues to be expressed while the fan-like dendrite is growing (Fig. 6) and remains present at least until hatching at E21. The high expression on Purkinje cells beginning at E15 is in line with the hypothesis that it may be a common denominator of cell-cell recognition processes involving developing and mature Purkinje cells. Analogous with other GPI-linked neural IgSF cell surface molecules, two different functions-as a receptor or as a ligand-can be taken into account.

\section{Is CEPU-1 a cellular receptor?}

CEPU-1 may represent a receptor or a subunit of a receptor complex and may be involved in conferring local environmental signals to the developing Purkinje cells. Some proteins linked to the membrane by a GPI-anchor and, hence, lacking an intracellular domain, nevertheless have been documented to transmit activation signals to cells, at least in the context of $\mathrm{T}$ cell activation (Gunter et al., 1987; Brown, 1993; Malek et al., 1994). The microenvironmental signals transmitted by CEPU-1 may comprise factors regulating Purkinje cell survival or differentiation by cell-cell interactions. For instance, in vitro coculture experiments suggest that Purkinje cell survival and differentiation are dependent on cell-cell interactions, predominantly with granule cells (Baptista et al., 1994). Similarly, granule cell proliferation and differentiation have also been shown to be dependent on local cell-cell interactions (Gao et al., 1992; Gao and Hatten, 1993). Furthermore, several studies provided evidence that interactions of Purkinje cell dendrites with parallel fibers play a prominent role in the regulation of dendritic growth (see references cited in Baptista et al., 1994).

\section{Does CEPU-1 represent a membrane-bound ligand?}

In contrast to a receptor function, CEPU-1 may also serve as a specific cell surface marker that is recognized by a receptor on other cells in the local environment. Because developing Purkinje cells are the only cells expressing CEPU- 1 in the cerebellar cortex between E15 and E19 (Figs. 4, 5), the protein may be a putative candidate for a Purkinje cell-specific cellular address molecule (Sperry, 1963). In cerebellar histogenesis, Purkinje cells are specifically identified in a complex cellular environment by axons of several other types of neurons (Eccles et al., 1967; Jacobson, 
1991), among them basket cell axons, stellate cell axons, parallel fibers, and climbing fibers. These cellular recognition events have in common that the Purkinje cells are the postsynaptic elements. A role as a ligand has also been demonstrated for other IgSF molecules, and both growth-promoting and growth-inhibiting molecules have been identified (for review, see Brümmendorf and Rathjen, 1995). By analogy, CEPU-1 may be involved in climbing fiber growth on the Purkinje cell dendrites, or it may represent a Purkinje cell-specific growth arrest signal, e.g., for basket cell axons or stellate cell axons. This growth arrest signal would not be unprecedented because a target cell-derived, contact-mediated stop signal has already been identified on other cerebellar neurons, the granule cells (Baird et al., 1992a,b).

However, CEPU-1 shows an unpolarized distribution in Purkinje cells. Therefore, it cannot bc solcly responsible for sclective recognition of subregions of the Purkinje cell surface by these axons; rather, it has to be assumed that other factors may contribute to the distinction of dendrite and soma by approaching afferents.

\section{CEPU-1 is not targeted to a specific subdomain of the Purkinje cell surface}

In contrast to epithelial cells, in which it is firmly established that GPI-anchored proteins are preferentially delivered to the apical membrane (Rodriguez Boulan and Powell, 1992), the subcellular targeting of GPI-anchored proteins within neurons seems to be dependent on multiple variables (Fuivre Sarrailh and Rougon, 1993). This is supported by the present study, which demonstrates that the GPI-linked molecule CEPU-1 is found in all subcellular compartments of the Purkinje cell.

\section{CEPU-1 shows high sequence similarity to neurotrimin, a differentially expressed neural cell surface molecule}

Chick CEPU-1 is highly related to rat neurotrimin, showing $78 \%$ amino acid sequence identity (Struyk et al., 1995). The degree of amino acid sequence similarity between rat and chick IgSF molecules considered to represent species homologs varies considerably, from 53\% (Thy-1) to 85\% (NCAM). Whereas this might be taken as evidence that CEPU-1 and neurotrimin represent species homologs, their spatial and temporal expression patterns are different, as follows.

First, neurotrimin and CEPU-1 differ with respect to their spatial and temporal expression pattern in developing cerebellum. Comparison of Purkinje cell development in chick (Fig. 5) and rat (Berry and Bradley, 1976; Takahashi Iwanaga et al., 1986) reveals that stage P7 in the rat corresponds to E16 in chicken and stage P14 in the rat corresponds to E18 in the chick. CEPU-1 is strongly expressed by Purkinje cells at E16 in chicken (Fig. 5), but neurotrimin is not found at P7, the corresponding stage, in the cerebellum of the rat (Struyk et al., 1995). Furthermore, CEPU-1 expression is restricted to Purkinje cells at E18 in the chick (Figs. 4, 5), but neurotrimin is found in both Purkinje cells and granule cells at P14, the corresponding stage, in the rat (Struyk et al., 1995).

Second, both molecules differ with respect to their temporal expression patterns in the forebrain. The neurotrimin expression level, quantified by immunoblot analysis, is increasing during development and is decreasing in the adult (Struyk et al., 1995). By contrast, the CEPU-1 expression level, examined by the same method, is steadily increasing during development and was not found to decline; rather, it increased in the adult (data not shown).

We therefore favor the view that both proteins represent two examples of a subfamily of closely related neural IgSF proteins that have similar primary structures but different expression patterns.

\section{CEPU-1 is a member of a new subfamily of neural IgSF cell recognition molecules}

In addition to neurotrimin, two other GPI-linked neural IgSF members with the same threc-domain structurc as CEPU-1 are known, namely OBCAM and LAMP (Lippman et al., 1992; Pimenta et al., 1995). The four proteins have $>54 \%$ sequence identity among each other and $<25 \%$ sequence identity to members of the F11 or L1 families of neural cell recognition molecules (Sonderegger and Rathjen, 1992; Brümmendorf and Rathjen, 1995 ) and, therefore, can be categorized into a new neural subgroup of the IgSF (Pimenta et al., 1995; Struyk et al., 1995). Molecules of this subgroup show the highest sequence conservation between species observed so far for IgSF molecules. For example, OBCAM as well as LAMP show $>98 \%$ sequence identity between the human and rat sequences (Pimenta et al., 1995; Shark and Lee, 1995). It is conceivable that CEPU-1 shares with OBCAM and LAMP this slow rate of evolutionary change.

With respect to its function, LAMP is currently the best characterized protein of this subgroup. It is expressed on limbic neurons and fiber tracts as well as in single layers of the superior colliculus, spinal cord, and cerebellum (Levitt, 1984; Horton and Levitt, 1988). The molecule has been shown to play a role in the invasion of the hippocampus by septal afferents and in the formation of the intrahippocampal mossy fiber projection, and it induces neurite outgrowth from perirhinal neurons (Keller et al., 1989; Pimenta et al., 1995; Zhukareva and Levitt, 1995).

Whereas neurotrimin and LAMP have complex developmental expression patterns, OBCAM shows a more restricted distribution (Levitt, 1984; Struyk et al., 1995). Interestingly, CEPU-1 is even more specifically expressed than OBCAM, as far as the rat and chick CNS can be compared. In the developing cerebellum, CEPU-1 expression is restricted to one single type of neuron, the Purkinje cell, and it is undetectable on other neurons like Golgi cells or granule cells. We consider it unlikely that CEPU-1 is expressed on basket cells or stellate cells, but we cannot formally exclude this possibility because these cells might be hidden by the Purkinje cell dendrites in the immunohistochemical analysis. In contrast to the differences in their expression patterns, these molecules have in common that they are expressed mainly by postmitotic neurons. For example, CEPU-1 is localized on Purkinje cells only after initiation of their differentiation (Fig. 5), and neurotrimin is found in the retinal ganglion cell layer but is absent from the mitotic cells of the retinal neuroepithelium.

It has been proposed that LAMP, OBCAM, and neurotrimin may serve as molecular labels of different types of neurons during embryonic development (Struyk et al., 1995; Zhukareva and Levitt, 1995). The role of CEPU-1 in the histogenesis of the cerebellar cortex is currently unknown, but it is conceivable that it may also represent a specific cell surface marker that is specifically recognized by receptors on interacting cells or approaching afferents. We will address this topic by using CEPU-1-specific antibodies, cerebellar cell cultures, and cerebellar slice cultures.

\section{REFERENCES}

Altman J, Bayer SA (1985) Embryonic development of the rat cerebellum. III. Regional differences in the time of origin, migration, and settling of Purkinje cells. J Comp Neurol 231:42-65. 
Baird DH, Baptista CA, Wang LC, Mason CA (1992a) Specificity of a target cell-derived stop signal for afferent axonal growth. J Neurobiol 23:579-591.

Baird DH, Hatten ME, Mason CA (1992b) Cerebellar target neurons provide a stop signal for afferent neurite extension in vitro. J Neurosci 12:619-634.

Baptista CA, Hatten ME, Blazeski R, Mason CA (1994) Cell-cell interactions influence survival and differentiation of purified Purkinje cells in vitro. Neuron 12:243-260.

Barami K, Kirschenbaum B, Lemmon V, Goldman SA (1994) $\mathrm{N}$-cadherin and NG-CAM/8D 9 are involved serially in the migration of newly generated neurons into the adult songbird brain. Neuron 13:567-582.

Barclay AN, Birkeland ML, Brown MH, Beyers AD, Davis SJ, Somoza C, Williams AF (1993) The leucocyte antigen facts book. London: Academic.

Berry M, Bradley P (1976) The growth of the dendritic trees of Purkinje cells in the cerebellum of the rat. Brain Res 112:1-35.

Bertossi M, Roncali L, Mancini L, Ribatti D, Nico B (1986) Process of differentiation of cerebellar Purkinje neurons in the chick embryo. Anat Embryol Berl 175:25-34.

Brown D (1993) The tyrosine kinase connection: how GPI-anchored proteins activate $T$ cells. Curr Opin Immunol 5:349-354.

Brümmendorf T, Rathjen FG (1993) Axonal glycoproteins with immunoglobulin- and fibronectin type III-related domains in vertebrates: structural fcatures, binding activitics and signal transduction. J Neurochem 61:1207-1219.

Brümmendorf T, Rathjen FG (1995) Cell adhesion molecules. I. Immunoglobulin superfamily. Prot Profile 2:963-1108.

Brümmendorf T, Wolff JM, Frank R, Rathjen FG (1989) Neural cell recognition molecule F11: homology with fibronectin type III and immunoglobulin type C domains. Neuron 2:1351-1361.

Brümmendorf T, Hubert M, Treubert U, Leuschner R, Tarnok A, Rathjen FG (1993) The axonal recognition molecule F11 is a multifunctional protein: specific domains mediate interactions with $\mathrm{Ng}$-CAM and restrictin. Neuron 10:711-727.

Chuong CM (1990) Differential roles of multiple adhesion molecules in cell migration: granule cell migration in cerebellum. Experientia 46:892-899.

Clark EA, Ledbetter JA (1994) How B and T cells talk to each other. Nature 367:425-428.

DeBernardo AP, Chang S (1995) Native and recombinant DM-GRASP selectively support neurite extension from neurons that express GRASP. Dev Biol 169:65-75.

Dodd J, Schuchardt A (1995) Axon guidance: a compelling case for repelling growth. Cell 81:471-474.

Doherty P, Walsh FS (1994) Signal transduction events underlying neurite outgrowth stimulated by cell adhesion molecules. Curr Opin Neurobiol 4:49-55.

Eccles JC, Ito M, Szentagothai J (1967) The cerebellum as a neuronal machine. Berlin: Springer.

Englund PT (1993) The structure and biosynthesis of glycosyl phosphatidylinositol protein anchors. Annu Rev Biochem 62:121-138.

Faivre Sarrailh C, Rougon G (1993) Are the glypiated adhesion molecules preferentially targeted to the axonal compartment? Mol Neurobiol 7:49 60 .

Feirabend HK (1990) Development of longitudinal patterns in the cerebellum of the chicken (Gallus domesticus): a cytoarchitectural study on the genesis of cerebellar modules. Eur J Morphol 28:169-223.

Foelix RF, Oppenheim R (1974) The development of synapses in the cerebellar cortex of the chick embryo. J Neurocytol 3:277-294.

Furley AJ, Morton SB, Manalo D, Karagogeos D, Dodd J, Jessell TM (1990) The axonal glycoprotein TAG-1 is an immunoglobulin superfamily member with neurite outgrowth-promoting activity. Cell $61: 157-170$.

Gao WQ, Hatten ME (1993) Neuronal differentiation rescued by implantation of weaver granule cell precursors into wild-type cercbellar cortex. Science 260:367-369.

Gao WQ, Liu XL, Hatten ME (1992) The weaver gene encodes a nonautonomous signal for CNS neuronal differentiation. Cell 68:841-854.

Gierer A, Müller CM (1995) Development of layers, maps and modules. Curr Opin Neurobiol 5:91-97.

Goodlett CR, Hamre KM, West JR (1990) Regional differences in the timing of dendritic outgrowth of Purkinje cells in the vermal cerebellum demonstrated by MAP2 immunocytochemistry. Brain Res Dev Brain Res 53:131-134.

Goodman CS, Shatz CJ (1993) Developmental mechanisms that generate precise patterns of neuronal connectivity. Cell [Suppl] 72:77-98.

Gunter KC, Germain RN, Kroczek RA, Saito T, Yokoyama WM, Chan C, Weiss A, Shevach EM (1987) Thy-1-mediated T-cell activation requires co-expression of CD3/Ti complex. Nature 326:505-507.

Hallonet ME, Teillet MA, Le Douarin NM (1990) A new approach to the development of the cerebellum provided by the quail-chick marker system. Development 108:19-31.

Hatten ME, Heintz N (1995) Mechanisms of neural patterning and specification in the developing cerebellum. Annu Rev Neurosci 18:385-408.

Hawkes R, Gravel C (1991) The modular cerebellum. Prog Neurobiol 36:309-327.

Hochuli E, Bannwarth W, Döbeli H, Gentz R, Stüber D (1988) Genetic approach to facilitate purification of recombinant proteins with a novel metal chelate adsorbent. Biotechnology 6:1321-1325.

Horton HL, Levitt $P$ (1988) A unique membrane protein is expressed on early developing limbic system axons and cortical targets. J Neurosci 8:4653-4661.

Hosoya H, Shimazaki K, Kobayashi S, Takahashi H, Shirasawa T, Takenawa T, Watanabe K (1995) Developmental expression of the neural cell adhesion molecule F3 in the rat brain. Neurosci Lett 186:83-86.

Hynes RO, Lander AD (1992) Contact and adhesive specificities in the associations, migrations, and targeting of cells and axons. Cell 68:303-322.

Jacobson M (1991) Developmental neurobiology. New York: Plenum.

Kapfhammer JP, Schwab ME (1992) Modulators of neuronal migration and neurite growth. Curr Opin Cell Biol 4:863-868.

Keller F, Rimvall K, Barbe MF, Levitt P (1989) A membrane glycoprotein associated with the limbic system mediates the formation of the septo-hippocampal pathway in vitro. Neuron 3:551-561.

Lanzillo JL (1991) Chemoluminescent nucleic acid detection with digoxigenin-labeled probes: a model system with probes for angiotensin converting enzyme which detect less than one attomole of target DNA. Anal Biochem 194:45-53.

Levitt P (1984) A monoclonal antibody to limbic system neurons. Science 223:299-301.

Lippman DA, Lee NM, Loh HH (1992) Opioid-binding cell adhesion molecule (OBCAM)-related clones from a rat brain cDNA library. Gene 117:249-254.

Malek TR, Fleming TJ, Codias EK (1994) Regulation of T lymphocyte function by glycosylphosphatidylinositol (GPI)-anchored proteins. Semin Immunol 6:105-113.

McKerracher L, David S, Jackson DL, Kottis V, Dunn RJ, Braun PE (1994) Identification of myelin-associated glycoprotein as a major myelin-derived inhibitor of neurite growth. Neuron 13:805-811.

Mierendorf RC, Percy C, Young RA (1987) Gene isolation by screening $\lambda \mathrm{gt} 11$ libraries with antibodies. Methods Enzymol 152:458-469.

Moran P, Caras IW (1991) Fusion of sequence elements from non-anchored proteins to generate a fully functional signal for glycophosphatidylinositol membrane anchor attachment. J Cell Biol 115:1595-1600.

Mukhopadhyay G, Doherty P, Walsh FS, Crocker PR, Filbin MT (1994) A novel role for myelin-associated glycoprotein as an inhibitor of axonal regeneration. Neuron 13:757-767.

Mullis KB, Faloona FA (1987) Specific synthesis of DNA in vitro via a polymerase catalysed-chain reaction. Methods Enzymol 155:335-350.

Nörenberg U, Hubert M, Brümmendorf T, Tarnok A, Rathjen FG (1995) Characterization of functional domains of the tenascin- $R$ (restrictin) polypeptide-cell attachment site, binding with F11, and enhancement of F11-mediated neurite outgrowth by tenascin-R. J Cell Biol 130:473-484.

Obata K, Fujita SC (1984) Developmental changes of chick cerebellar cortex revealed by monoclonal antibodies. Neurosci Res 1:117-129.

Ono K, Tomasiewicz H, Magnuson T, Rutishauser I (1994) N-C.AM mutation inhibits tangential neuronal migration and is phenocopied by enzymatic removal of polysialic acid. Neuron 13:595-609.

Palacios-Prü EL, Palacios L, Mcndoza RV (1981) Synaptogenctic mechanisms during chick cerebellar cortex development. J Submicrosc Cytol 13:145-167.

Peles E, Nativ M, Campbell PL, Sakurai T, Martinez R, Lev S, Clary DO, Schilling J, Barnea G, Plowman GD, Grumet M, Schlessinger J (1995) The carbonic anhydrase domain of receptor tyrosine phosphatase $\beta$ is a functional ligand for the axonal cell recognition molecule contactin. Cell 82:251-260. 
Pierceall WE, Cho KR, Getzenberg RH, Reale MA, Hedrick L, Vogelstein B, Fearon ER (1994) NIH3T3 cells expressing the deleted in colorectal cancer tumor suppressor gene product stimulate neurite outgrowth in rat PC12 pheochromocytoma cells. J Cell Biol 124:1017-1027.

Pimenta AF, Zhukareva V, Barbe MF, Reinoso BS, Grimley C, Henzel W, Fischer I, Levitt P (1995) The limbic system-associated membrane protein is an Ig superfamily member that mediates selective neuronal growth and axon targeting. Neuron 15:287-297.

Pourquie O, IIallonet MER, Le Douarin NM (1992) Association of BEN glycoprotein expression with climbing fiber axonogenesis in the avian cerebellum. J Neurosci 12:1548-1557.

Rathjen FG (1991) Neural cell contact and axonal growth. Curr Opin Cell Biol 3:992-1000.

Rathjen FG, Wolff JM, Frank R, Bonhoeffer F, Rutishauser U (1987) Membrane glycoproteins involved in neurite fasciculation. J Cell Biol 104:343-353.

Rathjen FG, Wolff JM, Chiquet Ehrismann R (1991) Restrictin: a chick neural extracellular matrix protein involved in cell attachment copurifies with the cell recognition molecule F11. Development 113:151-164

Reichardt LF, Tomaselli KJ (1991) Extracellular matrix molecules and their receptors: functions in neural development. Annu Rev Neurosci $14: 531-570$.

Rodriguez Boulan E, Powell SK (1992) Polarity of epithelial and neuronal cells. Annu Rev Cell Biol 8:395-427.

Rutishauser U (1993) Adhesion molecules of the nervous system. Curr Opin Neurobiol 3:709-715.

Sanger F, Nicklen S, Coulson AR (1977) DNA Sequencing with chainterminating inhibitors. Proc Natl Acad Sci USA 74:5463-5467.

Schwanzel Fukuda M, Reinhard GR, Abraham S, Crossin KL, Edelman GM, Pfaff DW (1994) Antibody to neural cell adhesion molecule can disrupt the migration of luteinizing hormone-releasing hormone neurons into the mouse brain. J Comp Neurol 342:174-185.

Shark KB, Lee NM (1995) Cloning, sequencing and localization to chromosome 11 of a cDNA encoding a human opioid-binding cell adhesion molecule (OBCAM). Gene 155:213-217.

Sheppard AM, Konopka M, Jeffrey PL (1988) The developmental appearance of Thy-1 in the avian cerebellum. Brain Res 468:181-192.

Small SJ, Shull GE, Santoni MJ, Akeson R (1987) Identification of a cDNA clone that contains the complete coding sequence for a $140 \mathrm{kDa}$ rat NCAM polypeptide. J Cell Biol 105:2335-2345.

Sonderegger P, Rathjen FG (1992) Regulation of axonal growth in the vertebrate nervous system by interactions between glycoproteins belonging to two subgroups of the immunoglobulin superfamily. J Cell Biol 119:1387-1394.
Sotelo C, Wassef M (1991) Cerebellar development: afferent organization and Purkinje cell heterogeneity. Philos Trans R Soc Lond [Biol] $331: 307-313$

Sperry RW (1963) Chemoaffinity in orderly growth of nerve fiher patterns and connections. Proc Natl Acad Sci USA 50:703-710.

Stoeckli ET, Landmesser L (1995) Axonin-1, Nr-CAM, and Ng-CAM play different roles in the in vivo guidance of chick commissural neurons. Neuron 14:1165-1179.

Struyk AF, Canoll PD, Wolfgang MJ, Rosen CL, Deustachio P, Salzer JL (1995) Cloning of neurotrimin defines a new subfamily of differentially expressed neural cell adhesion molecules. J Neurosci 15:2141-2156

Takahashi Iwanaga H, Kondo H, Yamakuni T, Takahashi Y (1986) An immunohistochemical study on the ontogeny of cells immunoreactive for spot 35 protein, a novel Purkinje cell-specific protein, in the rat cerebellum. Brain Res 394:225-231.

Tang J, Rutishauser U, Landmesser L (1994) Polysialic acid regulates growth cone behavior during sorting of motor axons in the plexus region. Neuron 13:405-414.

Tessier-Lavigne M (1994) Axon guidance by diffusible repellants and attractants. Curr Opin Genet Dev 4:596-601.

Tiveron MC, Barboni E, Pliego Rivero FB, Gormley AM, Seeley PJ, Grosveld F, Morris R (1992) Selective inhibition of neurite outgrowth on mature astrocytes by Thy-1 glycoprotein. Nature 355:745-748.

Udenfriend S, Kodukula K (1995) How glycosyl-phosphatidylinositolanchored membrane proteins are made. Annu Rev Biochem 64:563-591.

Uyemura K, Takeda Y, Asou H, Hayasaka K (1994) Neural cell adhesion proteins and neurolugical diseases. J Biochem Tokyo 116:1187-1192.

Wagner G, Wyss DF (1994) Cell surface adhesion receptors. Curr Opin Struct Biol 4:841-851.

Williams AF, Barclay AN (1988) The immunoglobulin superfamily: domains for cell surface recognition. Annu Rev Immunol 6:381-405.

Williams EJ, Furness J, Walsh FS, Doherty P (1994) Activation of the FGF receptor underlies neurite outgrowth stimulated by L1, N-CAM, and N-cadherin. Neuron 13:583-594.

Wolff JM, Brümmendorf T, Rathjen FG (1989) Neural cell recognition molecule F11: membrane interaction by covalently attached phosphatidylinositol. Biochem Biophys Res Commun 161:931-938.

Wong EV, Kenwrick S, Willems P, Lemmon V (1995) Mutations in the cell adhesion molecule LI cause mental retardation. Trends Neurosci 18:168-172.

Zhukareva V, Levitt P (1995) The limbic system-associated membrane protein (LAMP) selectively mediates interactions with specific central neuron populations. Development 121:1161-1172. 